\title{
Serum aminoterminal proctype natriuretic peptide in girls with idiopathic central precocious puberty during GNRHA treatment
}

\author{
Qiu-li Chen*, Hua-mei Ma, Zhe Su, Yan-hong Li, Hong-shan Chen, Min-lian Du \\ From 7th APPES Biennial Scientific Meeting \\ Nusa Dua, Bali. 14-17 November 2012
}

The mechanism of linear growth reduction during GnRHa treatment in central precocious puberty has not been elucidated.

\begin{abstract}
Aim
To investigate the pattern of serum amino-terminal proC-type natriuretic peptide (NT proCNP) in healthy girls throughout puberty, and the changes of serum NT proCNP in girls with idiopathic central precocious puberty (ICPP) before and during gonadotropin-releasing hormone analog $(\mathrm{GnRHa})$ therapy.
\end{abstract}

\section{Methods}

Serum levels of $E_{2}$, NT proCNP, insulin like growth factor 1(IGF1), NMID Osteocalcin(OC) and carboxy-terminal cross-linking telopeptide of type I collagen ( $\beta$-CrossLaps) were measured in healthy 57 girls at different pubertal stages, and in 13 girls with ICPP at the beginning and the end of $6^{\text {th }}$ month and $12^{\text {th }}$ month of GnRHa treatment. Height velocities of the 13 ICPP girls in each 6 months before and after $\mathrm{GnRHa}$ treatment was calculated.

\section{Results}

Serum NT proCNP level increases as the progress of pubertal development and peaks at the late puberty $(\mathrm{P}<0.01)$, paralleling with serum $E_{2}$ and IGF1 levels, like with the pattern of height velocity. All of serum NT proCNP, Osteocalcin and $\beta$-CrossLaps level decrease significantly in ICPP girls at the end of $6^{\text {th }}$ months of GnRHa therapy $(\mathrm{P}<0.01$ or $\mathrm{P}<0.05)$, and remain the same low level at the end of $12^{\text {th }}$ month of GnRHa. Different from the aboved markers, serum IGF1 level remains high before and during GnRHa treatment despite growth deceleration.

The first Affiliated Hospital of Sun Yat-Sen University, Guangzhou, China

\section{Conclusions}

Linear growth reduction in girls with ICPP treated with GnRHa is due at least in part to decreased CNP mediated long bone growth after estrogen inhibition. Serum NT proCNP can be used as a biological marker of long bone growth indicating the activity of epiphyseal growth plate.

Published: 3 October 2013

doi:10.1186/1687-9856-2013-S1-024

Cite this article as: Chen et al:: Serum aminoterminal proctype

natriuretic peptide in girls with idiopathic central precocious puberty during GNRHA treatment. International Journal of Pediatric Endocrinology 2013 2013(Suppl 1):O24.

\section{Submit your next manuscript to BioMed Central and take full advantage of: \\ - Convenient online submission \\ - Thorough peer review \\ - No space constraints or color figure charges \\ - Immediate publication on acceptance \\ - Inclusion in PubMed, CAS, Scopus and Google Scholar \\ - Research which is freely available for redistribution

